\title{
Performance of multi-soil-layering (MSL) urban domestic wastewater treatment system
}

\author{
Haribowo R. ${ }^{1}$, Prayogo T.B. ${ }^{1}$, Shaleha N.N. ${ }^{1}$, Hafni K.N. ${ }^{2}$ \\ ${ }^{1}$ Water Resources Department, Faculty of Engineering, Universitas Brawijaya, 65145 \\ Malang, Jawa Timur, Indonesia \\ ${ }^{2}$ Environmental Engineering Department, Faculty of Engineering, University of North \\ Sumatra, Medan, 20222, North Sumatra, Indonesia \\ riyanto_haribowo@ub.ac.id \\ Received 19-01-2020; accepted 26-03-2020
}

\begin{abstract}
This research has the objective of examining the efficiency optimization of a multisoil-layering (MSL) system in three stages through the selection of the most efficient material for permeable layers. The utilized charcoal variations were coconut shell charcoal, rice husk charcoal, and corncob charcoal. The utilized incoming discharge for Q1 and Q2 were 0.0063 $\mathrm{L} /$ second and $0.0126 \mathrm{~L} /$ second. In the first stage of processing, the pumice and zeolite in Q1 had not been able to reduce the TSS below the quality standard, while silica sand in both discharges were still in accordance with the quality standard. In the second stage of processing, Q1 MSL A-s had the best elimination capability, with the efficiencies of TDS, TSS, $\mathrm{pH}$, and DO respectively being $18.13 \%, 79.68 \%, 2.60 \%$, and $126.67 \%$, while for Q2, they were $29.99 \%, 77.76 \%, 1.62 \%$, and $95.80 \%$. In the third stage, it was shown that MSL B-m was the most optimal reactor compared to all reactors that had their water qualities measured. For Q1 for MSL B-m, the parameters of TDS, TSS, $\mathrm{pH}$, and DO were respectively $33.16 \%, 84.32 \%$, $1.29 \%$, and $126.67 \%$, and for Q2 they were $30.80 \%, 80.54 \%, 1.50 \%$, and $112.30 \%$. In the third stage of processing, MSL A-m, MSL B-m, and MSL C-m that included the addition of soil mixtures and modifications of soil mixture blocks could increase the efficiency of each parameter and had a more stable quality of water outflow compared to standard MSL; this is because the incoming water flow was slower, which caused water contact with the processing media to be more optimal.
\end{abstract}

Keywords: Multi-soil-layering, wastewater treatment, domestic wastewater

\section{Introduction}

Soil as a natural filtration medium has long been used in the process of water purification, and one of the utilized methods is multi-soil-layering (MSL). Various research and studies have been conducted to increase the capabilities because this system is cheap in its operations and maintenance, easy to construct and operate, and can utilize local materials. The problem that is discovered in major

Cite this as: Haribowo, R., Prayogo, T.B., Shaleha, N.N., \& Hafni, K.N. (2000). Performance of multi-soillayering (MSL) urban domestic wastewater treatment system. Civil and Environmental Science Journal, 3(1), pp.37-50. doi: https://doi.org/10.21776/ub.civense.2020.00301.5 
cities in the rivers as the bodies of water that pass through them, such as the Ciliwung, Bengawan Solo, and Brantas rivers as well as others, is the entry of pollutants into the river water, which is dominated by both processed and unprocessed domestic wastewater [9, 10].

This research involves performing optimization of MSL system reactors to compare MSL effluents with the effluents of the integrated public sanitation (MCK) system that is currently installed at Tlogomas using two different discharges for the parameters of $\mathrm{pH}$, Total Suspended Solids (TSS), Total Dissolved Solids (TDS), and Dissolved Oxygen (DO) [11]. The values of these parameters are compared with that for water quality based on Government of the Republic of Indonesia Regulation No. 82/2001 on the Management of Water Quality and Control of Water Pollution and Ministry of the Environment and Forestry Regulation No. 68 of Year 2016 on the Domestic Wastewater Quality Standard [4]. Both discharges are based on the current estimation of produced domestic waste output as well as the projected output of waste in the future based on the increase in population [6].

Optimization of the MSL system is focused on the selection of the best permeable layer to be combined with several kinds of soil mixture blocks with different kinds of charcoal, as well as to see the increase in the efficiency of the MSL system when modifications of the soil mixture block shapes are applied $[1,2]$.

The different kinds of permeable zeolite, zeolite-resembling material, perlite, rock, and charcoal layers gave different values of efficiency in the elimination of dissolved $\mathrm{COD}, \mathrm{BOD}_{5}$, and reactive phosphorus [3]. The efficiency of elimination also depended on the operational condition of whether or not aeration was given. In a research by Megah [7], permeable layers of zeolite, gravel, and gravelzeolite mixture had not been able to meet the quality standards according to Ministry of the Environment and Forestry Regulation No. 68 of Year 2016 on the Domestic Wastewater Quality Standard for the parameter of Total Suspended Solids (TSS). This was also the case after the permeable layer was combined with soil block mixtures composed of variations of andosol soil mixed with coconut shell charcoal, rice straw charcoal, and sawdust with a ratio of 2:1 [8]. This was in accordance with the research by Megah [7], in which it was proved that the permeable layer affected the process of water purification, particularly in the elimination of dissolved solids.

Guan et al. [3] stated that the quantitative evaluation of water movement in MSL is not sufficient for understanding and suggested the use of Retention Distribution Time (RTD) as the method for the characterization of mixtures and flows in an MSL reactor using pulse tracer tests. The results of the research indicated that the level of re-dispersion of MSL is a moderate dispersion for HLR of 200, 400,800 , and $1,600 \mathrm{~L} /\left(\mathrm{m}^{2} . \mathrm{d}\right)$ with the RTD showing a Continuous Stirrer Tank Reactor (CSTR) flow pattern as well as a negative correlation with the dead zone. The dead zone ratios of the MSL were $41.0 \%, 52.3 \%, 59.6 \%$, and $38.8 \%$ for HLR of $200,400,800$, and $1,600 \mathrm{~L} /\left(\mathrm{m}^{2} . \mathrm{d}\right)$. This research was in line with the study performed by Latrach $[5,6]$ in that the manipulation of influent flow patterns with modification of the soil mixture block layer shape can increase the efficiency of MSL. This research is to optimize an MSL system that may be applied in the processing of domestic wastewater of the Integrated Public Sanitation at Tlogomas Hamlet, Malang, which is expected to be able to be implemented in the current system and will have an effect on the optimization of land use and beneficial utilization of wastewater before being drained into the river.

\section{Material and Methods}

The location of the research is Tlogomas Hamlet in Lowokwaru Sub-District, City of Malang. Tlogomas Hamlet is one of the 12 hamlets in Lowokwaru Sub-District in the City of Malang (Satria, 2013). The research site is the wastewater treatment facility (IPAL) in RT.04 RW.07 in Tlogomas Sub-District (Figure 1 and Figure 2). 


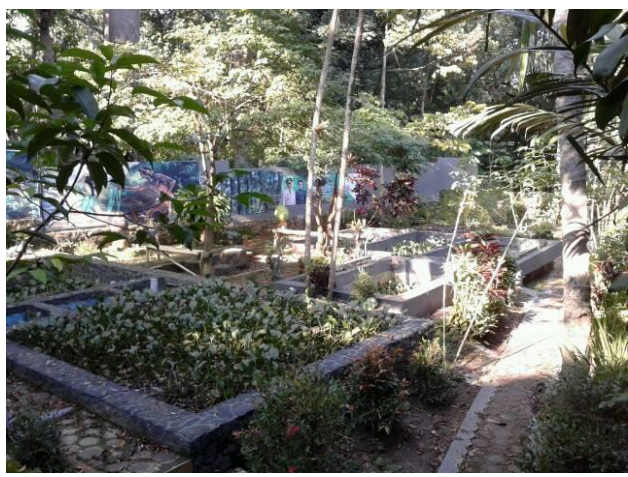

Figure 1. Integrated Public Sanitation Wastewater Treatment Facility (IPAL MCK), Jl. Tirta Rona

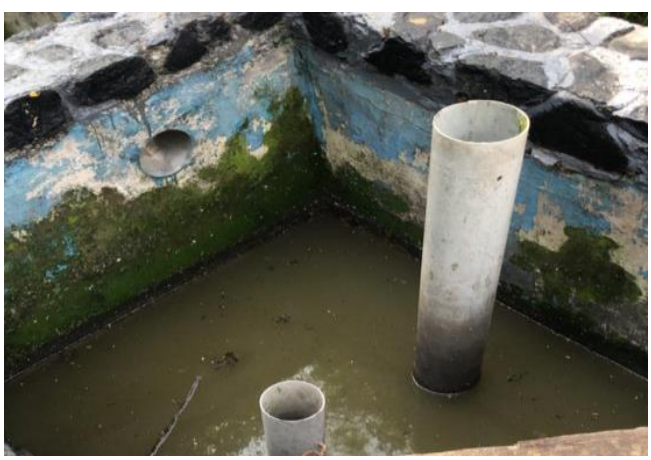

Figure 2. Aeration Pond I, Sample Collection Site for the IPAL MCK

\section{Calculation of Effluent Average Discharge}

The calculated average wastewater discharge is the wastewater discharge that originates from household connections (SR) and public hydrants (HU). As the inflow discharge value for the MSL reactor, the resulting wastewater outflow discharge was assumed to be $80 \%$ of the clean water discharge of household connections and public hydrants, or can be taken as a wastewater generation rate (fab) of 0.8 . The wastewater discharge can be calculated using the following formula:

$\mathrm{Qr}=\frac{\text { fab } \times[(80 \% \times \text { household water needs }(\mathrm{SR}) \times \mathrm{n} \text { number of residents })+(20 \% \mathrm{x} \text { hydrant water needs })]}{86,400 \text { second } / \text { day }}$.

Where:

Qr: Average wastewater discharge (L/second)

Wastewater generation rate: 0.8

Domestic water needs for household connections: $170 \mathrm{~L} /$ person/day

Water needs for public hydrants: $30 \mathrm{~L} /$ person/day

Number of residents served: 5 people

Calculation of wastewater discharge:

$\mathrm{Qr}=(0.8 \times[(80 \% \times 170 \times 5)+(20 \% \times 30)]) /(86400)$

Qr $=0.0063 \mathrm{~L} /$ second or $378 \mathrm{~mL} /$ minute

From the above calculations, the wastewater discharge which flows into the MSL reactor was found to be $0.0063 \mathrm{~L} /$ second. For the $\mathrm{Q}_{2}$ discharge, it was assumed to be twice as large as $\mathrm{Q}_{1}$, and therefore the $\mathrm{Q}_{2}$ discharge has a rate of $0.0126 \mathrm{~L} / \mathrm{second}$ or $576 \mathrm{~mL} / \mathrm{minute}$. The control and installation of discharge for the reactor utilized the method of valve opening, wherein the size of the primary valve opening was controlled in order to result in a discharge that is in accordance with calculations.

\section{MSL Reactor Planning}

In this research, the reactor dimensions were determined based on the inflow discharge as well as the filtration speed of the rapid filter as designated in SNI 6774:2008 [7], which is $6 \mathrm{~m} /$ hour. The following is the systematic calculation of reactor dimensions using Equation 2 below:

$$
\begin{aligned}
& \text { As }=\frac{\mathrm{Q}}{\mathrm{Vo}} \ldots \ldots \ldots \ldots \ldots \ldots . . . \ldots . \ldots \\
& \text { As }=\frac{0.0063 \mathrm{~L} / \text { second }}{6 \mathrm{~m} / \mathrm{hour}}
\end{aligned}
$$


As $=0.0033 \mathrm{~m}^{2}=33.33 \mathrm{~cm}^{2}$

With As or the calculation area amounted to $33.33 \mathrm{~cm}^{2}$ then obtained the dimension value,

$\mathrm{As}=\mathrm{As}_{(\text {design })}$

33.33 = length $\mathrm{x}$ width $=8.2 \times 4.1$

$33.33=33.62$ (sufficient)

The planned dimensions of the reactors were $8.2 \times 4.1 \mathrm{~cm}$, but because of calculations of retention time, the dimensions were increased to five times larger than the planned dimensions. The height of the reactors were determined based on the total thicknesses of the gravel layer $(5 \mathrm{~cm})$, sand layer $(25$ $\mathrm{cm})$, soil mixture block layer $(20 \mathrm{~cm})$, and the distance between the surface of the sand layer with the inlet pipe $(5 \mathrm{~cm})$, and the resulting reactor height was $55 \mathrm{~cm}$. Thus, the dimensions of the MSL reactor were $41 \mathrm{~cm}$ x $20.5 \mathrm{~cm}$ x $55 \mathrm{~cm}$. Domestic wastewater treatment using an MSL system consisted of the following three stages of processing:

1. The first stage of processing has the objective to process the wastewater using a reactor filled with rocks composed of zeolite, silica sand, and pumice with 3-5 mm diameters. The most optimal rock filler is to be used in the second and third stages of processing as a filler layer between soil mixture blocks. The dimensions of the rock filler has a length $\mathrm{x}$ width $\mathrm{x}$ height of $41 \mathrm{~cm}$ x $20.5 \mathrm{~cm} \times 40 \mathrm{~cm}$ (Figure 3).

2. The second stage of processing involved the use of combinations soil mixture blocks with the previously selected rock filler layer. The composition of soil mixture blocks for each reactor is made up of andosol soil, sawdust, iron powder, and charcoal variations at a ratio of 7:1:1:1. The MSL-standard reactors are composed of MSL A-s that utilized coconut shell charcoal, MSL B-s that utilized rice husk charcoal, and MSL C-s that utilized corncob charcoal. The dimensions of the soil mixture blocks were $8 \mathrm{~cm} \times 20.5 \mathrm{~cm} \times 5 \mathrm{~cm}$ in length $\mathrm{x}$ width $\mathrm{x}$ height (Figure 4).

3. The third stage of processing involved processing with modification of the shape of the soil mixture in the second stage of processing. If in the previous stage the soil mixture was shaped into rectangular blocks, in this stage the blocks were modified into the shape of a letter "U". The modified soil mixture block in the third stage of processing has the objective to optimize the flow of wastewater in the reactor and reduce reactor areas where the flow does not go through (dead zone). The utilized dimensions are the same as with previous dimensions $(8 \mathrm{~cm}$ x $20.5 \mathrm{~cm} \times 5 \mathrm{~cm}$ ) with the addition of blocks on the left and right with dimensions of $2 \mathrm{~cm} \mathrm{x}$ $20.5 \mathrm{~cm} \times 3$ (Figure 5).

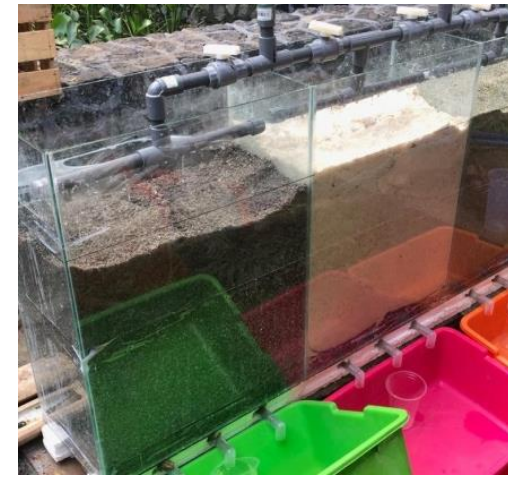

Figure 3. Reactor Installation in the First Stage Processing

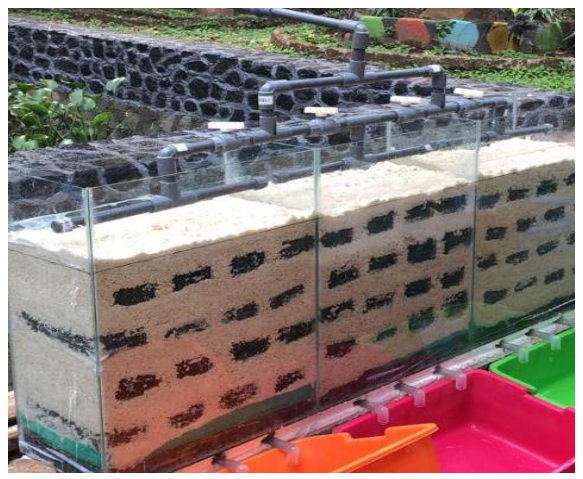

Figure 4. Reactor Installation in Second Stage Processing

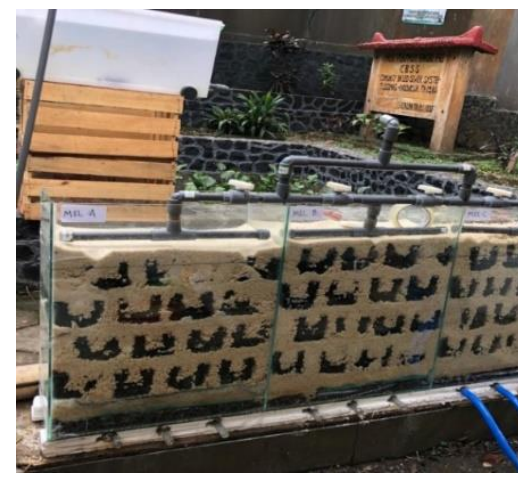

Figure 5. Reactor Installation in the Third Stage Processing 


\section{Parameter Measurement}

The parameters that were measured are $\mathrm{pH}$, Total Dissolved Solids (TDS), Dissolved Oxygen (DO), and Total Suspended Solids (TSS). The utilized discharge had a value of $0.0063 \mathrm{~L} / \mathrm{second}$ for Q1 and $0.0126 \mathrm{~L} / \mathrm{second}$ for Q2. Measurements were performed every 15 minutes for 2.5 hours. The resulting average outflow water quality of the reactor was compared with the Integrated Public Sanitation outlet water quality and quality standards based on existing regulations (Table 1).

Table 1. Quality Standard for Domestic Wastewater

\begin{tabular}{|c|c|c|c|}
\hline No & Parameter & Unit & Maximum content \\
\hline 1 & TSS & $\mathrm{mg} / \mathrm{L}$ & 30 \\
\hline 2 & TDS & $\mathrm{mg} / \mathrm{L}$ & 1000 \\
\hline 3 & DO & $\mathrm{mg} / \mathrm{L}$ & 3 \\
\hline 4 & $\mathrm{pH}$ & - & $6.0-9.0$ \\
\hline
\end{tabular}

\section{Calculation of Removal and Improvement Efficiency}

What is meant by efficiency is the comparison of increase or decrease in the initial content of waste with the content of waste after processing with the stages of multi-soil-layering (MSL). This allows to see whether processing using this method is efficient in decreasing waste content that exceeds environmental quality standards. Efficiency of wastewater parameter reduction is calculated with the formula below:

Elimination $(\%)=\left|\frac{\text { initial concentration-final concentration }}{\text { initial concentration }}\right| \times 100 \%$

Calculation of enhancement efficiency is performed with the formula below:

Enhancement $(\%)=\left|\frac{\text { final concentration-initial concentration }}{\text { initial concentration }}\right| \times 100 \%$

\section{Determination of the Best Reactor with Scoring Method}

To determine the best reactor to be used in stages I, II, and III, a simple scoring method was utilized. Weighting was performed through the evaluation of average measurement results for each parameter in both discharges to determine scores to be given based on specific criteria:

a) For each parameter, if the average measurement for each discharge meets the quality standard of Ministry of the Environment and Forestry Regulation No. 68 of Year 2016 on the Domestic Wastewater Quality Standard and Government of the Republic of Indonesia Regulation No. 82/2001 on the Management of Water Quality and Control of Water Pollution, a score of 1 is given, and a score of 0 otherwise.

b) The best processing was given a weighted score of 3 , the next-best was given a weighted score of 2 , and the worst was given a weighted score of 1 for each parameter for both discharges.

\section{Result and Discussion}

3.1 Measurement of the Existing Water Quality of the Integrated Sanitation Facility at Tlogomas

The utilized domestic wastewater came from the waste that entered the Integrated Sanitation Facility at Tlogomas. The sampling points consisted of two points, which were Aeration Pond I and the Integrated Sanitation Facility Outlet. Sampling taken from Aeration Pond I was taken as the influent waste for the entire research. To compare the quality of outflow water or effluent from the MSL system, measurements needed to be taken from the Integrated Sanitation Facility Outlet in order to be able to make a comparison. Measurement of water quality used the Water Quality Checker 
Horiba Series U-50 tool for the parameters of pH, TDS, and DO, and the Insite IG Series 3150 tool for the parameter of TSS. Measurements were taken at 6:00 AM, 12:00 PM, and 6:00 PM, considering that domestic waste is generally discharged in the morning and the afternoon (Table 2).

Table 2. Existing Water Quality of the Integrated Sanitation Facility at Tlogomas

\begin{tabular}{|c|c|c|c|c|c|c|c|c|c|}
\hline \multirow[b]{3}{*}{ No. } & \multirow[b]{3}{*}{ Parameter } & \multirow[b]{3}{*}{ Unit } & \multicolumn{6}{|c|}{ Hour } & \multirow[b]{3}{*}{$\begin{array}{l}\text { Quality } \\
\text { standard }\end{array}$} \\
\hline & & & \multicolumn{2}{|c|}{ 6:00 AM } & \multicolumn{2}{|c|}{ 12:00 PM } & \multicolumn{2}{|c|}{ 06:00 PM } & \\
\hline & & & $\begin{array}{c}\text { Aeration } \\
\text { Pond I }\end{array}$ & $\begin{array}{c}\text { Integrated } \\
\text { Sanitation } \\
\text { Outlet }\end{array}$ & $\begin{array}{c}\text { Aeration } \\
\text { Pond I }\end{array}$ & $\begin{array}{c}\text { Integrated } \\
\text { Sanitation } \\
\text { Outlet }\end{array}$ & $\begin{array}{c}\text { Aeration } \\
\text { Pond I }\end{array}$ & $\begin{array}{c}\text { Integrated } \\
\text { Sanitation } \\
\text { Outlet }\end{array}$ & \\
\hline 1 & $\mathrm{pH}$ & - & 7.04 & 7.21 & 6.95 & 7.47 & 6.94 & 7.32 & $6,00-9.00$ \\
\hline 2 & DO & $\mathrm{mg} / \mathrm{L}$ & 0 & 2.08 & 0 & 1.29 & 0 & 0.95 & 3 \\
\hline 3 & TDS & $\mathrm{mg} / \mathrm{L}$ & 711 & 568 & 691 & 576 & 656 & 584 & 1000 \\
\hline 4 & TSS & $\mathrm{mg} / \mathrm{L}$ & 67 & 29 & 72 & 30 & 77 & 27 & 30 \\
\hline
\end{tabular}

Based on Ministry of the Environment and Forestry Regulation No. 68 of Year 2016 on the Domestic Wastewater Quality Standard, the water quality at the sampling points still have not met the established quality standards, still in excess of $30 \mathrm{mg} / \mathrm{L}$ for the TSS parameter and less than $3 \mathrm{mg} / \mathrm{L}$ for the DO parameter. However, $\mathrm{pH}$ and TDS are in line with the established quality standards. The pH parameter is in line with Ministry of the Environment and Forestry Regulation No. 68 of Year 2016 and the TDS parameter is in line with Government of the Republic of Indonesia Regulation No. $82 / 2001$.

\subsection{First Stage Processing}

Based on the results of measurements for 2.5 hours, 10 sets of observation data were obtained for each parameter for $\mathrm{Q}_{1}$ and $\mathrm{Q}_{2}$. By calculating the average value of each data set, values can be obtained that represent the resulting outflow water quality from each reactor (Table 3 ).

Table 3. Recapitulation of Water Quality Measurement in Stage I Processing

\begin{tabular}{|c|c|c|c|c|c|c|c|}
\hline \multirow[b]{2}{*}{ Parameter } & \multirow{2}{*}{ Discharge } & \multirow{2}{*}{$\begin{array}{c}\text { Aeration } \\
\text { Pond I }\end{array}$} & \multicolumn{3}{|c|}{ Reactor } & \multirow{2}{*}{$\begin{array}{c}\text { Integrated } \\
\text { Sanitation } \\
\text { Outlet }\end{array}$} & \multirow{2}{*}{$\begin{array}{l}\text { Quality } \\
\text { standard }\end{array}$} \\
\hline & & & Pumice & Silica Sand & Zeolite & & \\
\hline \multirow{2}{*}{$\mathrm{pH}$} & $\mathrm{Q}_{1}$ & 7.18 & 7.44 & 7.47 & 7.56 & \multirow{2}{*}{7.32} & \multirow{2}{*}{$\begin{array}{l}6.00- \\
9.00\end{array}$} \\
\hline & $\mathrm{Q}_{2}$ & 7.33 & 7.36 & 7.37 & 7.50 & & \\
\hline \multirow{2}{*}{ TDS (mg/l) } & $\mathrm{Q}_{1}$ & 653 & 578 & 582 & 526 & \multirow{2}{*}{584} & \multirow{2}{*}{1000} \\
\hline & $\mathrm{Q}_{2}$ & 653 & 610 & 605 & 540 & & \\
\hline \multirow{2}{*}{ TSS (mg/l) } & $\mathrm{Q}_{1}$ & 70 & 43.40 & 12.60 & 34.20 & \multirow{2}{*}{27.00} & \multirow[t]{2}{*}{0} \\
\hline & $\mathrm{Q}_{2}$ & 70 & 51.60 & 24.80 & 27.10 & & \\
\hline \multirow{2}{*}{$\mathrm{DO}(\mathrm{mg} / \mathrm{l})$} & $\mathrm{Q}_{1}$ & 0.00 & 4.51 & 3.85 & 4.23 & \multirow{2}{*}{0.95} & \multirow[b]{2}{*}{3} \\
\hline & $\mathrm{Q}_{2}$ & 0.39 & 3.56 & 3.60 & 3.90 & & \\
\hline
\end{tabular}

The $\mathrm{pH}$ parameter for each reactor composed of pumice, silica sand, and zeolite could all meet the quality standard from 6.00-9.00. When compared with the results from the Integrated Sanitation outlet, the capabilities of the three first-stage processing reactors in neutralizing $\mathrm{pH}$ are not quite good. For the TDS parameter, the three first-stage processing reactors could meet the quality standard of below $1,000 \mathrm{mg} / \mathrm{L}$, but when compared with the Integrated Sanitation outlet, only the reactor filled with zeolite had the best processing result. For the TSS parameter, only the reactor filled with silica sand could meet the TSS quality standard of below $30 \mathrm{mg} / \mathrm{L}$, and when compared with the Integrated Sanitation outlet, the conclusion is that the silica sand reactor is the best in processing suspended 
solids in domestic waste. For the last parameter of DO, the three reactors could meet Class III quality standard of above $3 \mathrm{mg} / \mathrm{L}$, and when compared with the Integrated Sanitation outlet, the conclusion is that the three reactor fillers can result in a better concentration of DO (Table 3 ).

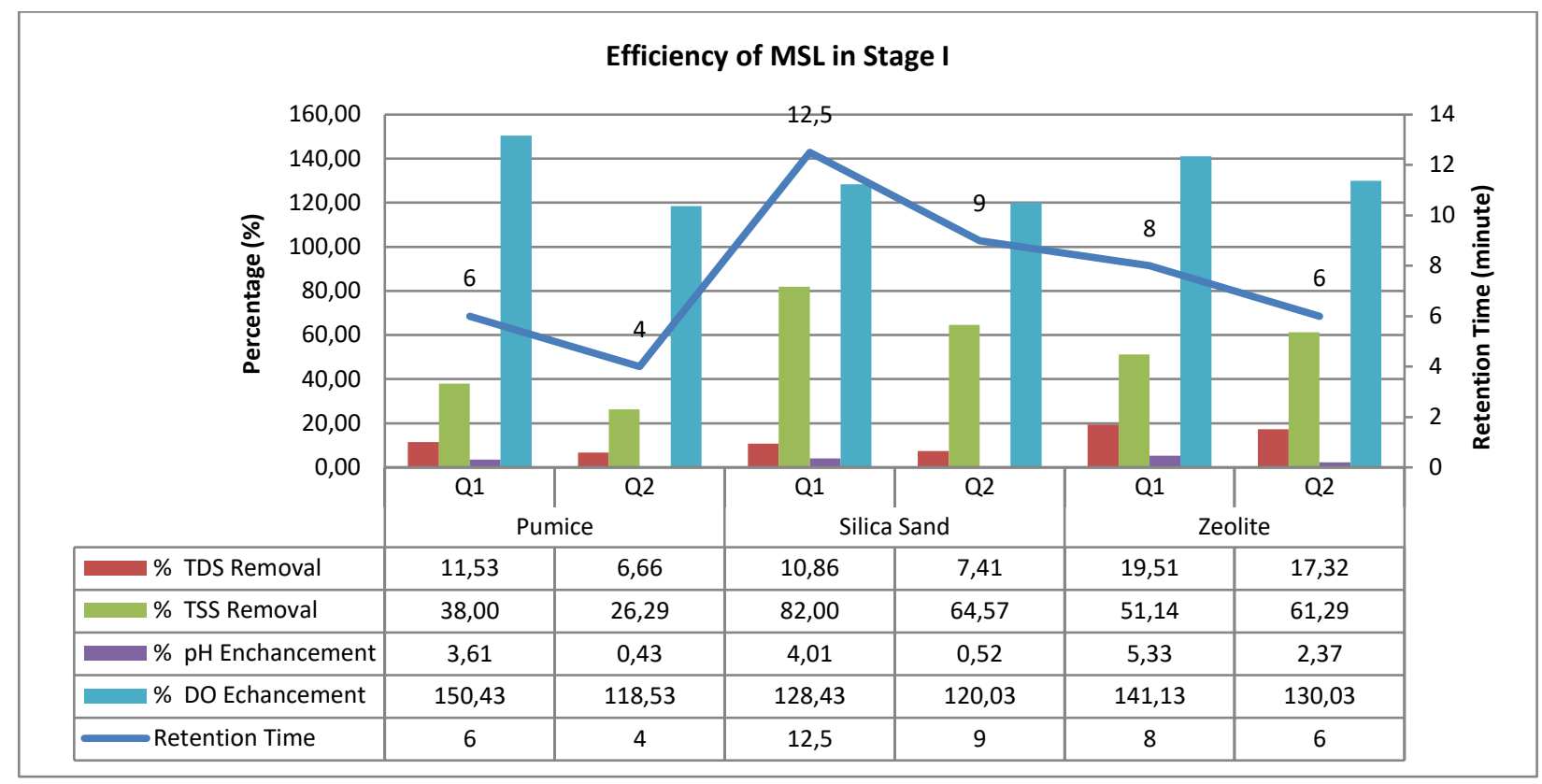

Figure 6. Reactor Efficiency for the First Stage of Processing

For the $\mathrm{pH}$ parameter, zeolite at $\mathrm{Q}_{2}$ had the highest average $\mathrm{pH}$ efficiency enhancement with $5.33 \%$, followed by silica sand at $\mathrm{Q}_{1}$ with $4.01 \%$ and pumice at $\mathrm{Q}_{1}$ with $3.61 \%$. Enhancement of $\mathrm{pH}$ was not uniform for both discharges; this is in line with the results of the study by Deshpande [12] who explained that the effluent reactor $\mathrm{pH}$ in general is not affected by the influent flow rate and the aerated or non-aerated condition of the MSL system.

The percentages of efficiency of each reactor for TDS with an influent of $653 \mathrm{mg} / \mathrm{L}$ at $\mathrm{Q}_{1}$ was $11.53 \%$ for pumice, $10.86 \%$ for silica sand, and $19.51 \%$ for zeolite. Meanwhile at $\mathrm{Q}_{2}$, they were $6.66 \%, 7.41 \%$, and $17.32 \%$ for pumice, silica sand, and zeolite respectively. The highest efficiency was with zeolite; this is because the pore affinity of pumice and between granules of pumice is smaller than that between granules of silica.

The efficiencies of TSS concentration elimination at $\mathrm{Q}_{1}$ were $38.00 \%$ with a pumice reactor, $82.00 \%$ with silica sand, and $51.14 \%$ with zeolite. Meanwhile at $\mathrm{Q}_{2}$, the efficiencies were $26.29 \%$, $64.57 \%$, and $61.29 \%$ for pumice, silica sand, and zeolite respectively. TSS efficiency is linear in nature, where a greater discharge leads to a smaller elimination percentage. This indicates that the function of intra-granular and inter-granular pores of permeable layers play an important role. This condition is in line with the observations by Deshpande [12] who found that the best TSS elimination is achieved through the filtration process with permeable layers and soil mixture block layers. On average, silica sand could eliminate TSS well at the $\mathrm{Q}_{1}$ and $\mathrm{Q}_{2}$ discharges.

The three permeable layers could increase the level of dissolved oxygen in effluents above 3 $\mathrm{mg} / \mathrm{L}$ at both $\mathrm{Q}_{1}$ and $\mathrm{Q}_{2}$ (with percentages greater than $100 \%$ ) with $150.43 \%, 128.43 \%$, and $141.13 \%$ at $\mathrm{Q}_{1}$ and $121.30 \%, 123.03 \%$, and $134.52 \%$ at $\mathrm{Q}_{2}$ respectively for permeable layers of pumice, silica sand, and zeolite. With $\mathrm{Q}_{2}$, the results of efficiency enhancement were in an inverse relationship with the enhancement of dissolved oxygen; this may be possible because of the further reduced contact time with the aerobic area. This is in line with Yidong et al. [13] who found that oxygen is trapped in the pores of permeable layers, and at a high discharge these pores are filled with wastewater (Figure $6)$. 
Table 4. Selection of the Best Reactor in Stage I of Processing

\begin{tabular}{|c|c|c|c|c|c|c|c|}
\hline \multirow{2}{*}{ Parameter } & \multirow{2}{*}{ Factor } & \multicolumn{3}{|c|}{ Q1 } & \multicolumn{3}{|c|}{ Q2 } \\
\hline & & Pumice & Silica Sand & Zeolite & Pumice & Silica Sand & Zeolite \\
\hline \multirow{2}{*}{$\mathrm{pH}$} & Meets Quality Standard & 1 & 1 & 1 & 1 & 1 & 1 \\
\hline & Best Ranking & 3 & 2 & 1 & 3 & 2 & 1 \\
\hline \multirow{2}{*}{ TDS } & Meets Quality Standard & 1 & 1 & 1 & 1 & 1 & 1 \\
\hline & Best Ranking & 2 & 2 & 1 & 3 & 2 & 1 \\
\hline \multirow{2}{*}{ TSS } & Meets Quality Standard & 0 & 1 & 0 & 0 & 1 & 1 \\
\hline & Best Ranking & 1 & 3 & 2 & 1 & 3 & 2 \\
\hline \multirow{2}{*}{ DO } & Meets Quality Standard & 1 & 1 & 1 & 1 & 1 & 1 \\
\hline & Best Ranking & 3 & 1 & 2 & 1 & 2 & 3 \\
\hline & Total Score & 12 & 12 & 9 & 11 & 13 & 11 \\
\hline \multicolumn{2}{|c|}{ Total Score for Pumice, Both Discharges } & 23 & & & & & \\
\hline \multicolumn{2}{|c|}{ Total Score for Silica Sand, Both Discharges } & 25 & & & & & \\
\hline \multicolumn{2}{|c|}{ Total Score for Zeolite, Both Discharges } & 20 & & & & & \\
\hline
\end{tabular}

Referring to the results of effluent water quality measurements in Table 3, the best reactor was selected in this stage of processing by considering whether the reactor effluents meet the quality standard of each parameter and the best processing ranking in eliminating pollutants. From the simple weighing method, the largest score was found to be 25 for reactor 2 with silica sand (Table 4). Silica sand was selected to be used as the permeable layer medium in the next stage, considering that silica sand at each stage met the criteria, while zeolite was found to have failed once for the TSS parameter at the $\mathrm{Q}_{1}$ discharge. The media of zeolite and silica sand are commonly used media in the process of water purification and their respective advantages and disadvantages being due to porosity, formation structure, chemical composition, and ion exchange capabilities of each media.

\subsection{Second Stage of Processing}

Based on the results of measurement for 2.5 hours, 10 sets of observation data were obtained for each parameter at $\mathrm{Q}_{1}$ and $\mathrm{Q}_{2}$. Calculating the average values of the data gives a value that represents the resulting quality of outflow water from each reactor.

Table 5. Summary of Water Quality Measurement for Stage II of Processing

\begin{tabular}{|c|c|c|c|c|c|c|c|}
\hline \multirow{2}{*}{ Parameter } & \multirow{2}{*}{ Discharge } & \multirow{2}{*}{$\begin{array}{c}\text { Aeration } \\
\text { Pond I }\end{array}$} & \multicolumn{3}{|c|}{ Reactor } & \multirow{2}{*}{$\begin{array}{c}\text { Integrated Sanitation } \\
\text { Outlet } \\
\end{array}$} & \multirow{2}{*}{$\begin{array}{c}\text { Quality } \\
\text { standard }\end{array}$} \\
\hline & & & MSL A-s & MSL B-S & MSL C-s & & \\
\hline \multirow{2}{*}{$\mathrm{pH}$} & $\mathrm{Q}_{1}$ & 6.99 & 7.17 & 7.07 & 7.12 & \multirow{2}{*}{7.32} & \multirow{2}{*}{$6.00-9.00$} \\
\hline & $\mathrm{Q}_{2}$ & 6.96 & 6.85 & 6.91 & 6.95 & & \\
\hline \multirow{2}{*}{ TDS (mg/l) } & $\mathrm{Q}_{1}$ & 651 & 533 & 547 & 613 & \multirow{2}{*}{584} & \multirow{2}{*}{1000} \\
\hline & $\mathrm{Q}_{2}$ & 675 & 473 & 515 & 553 & & \\
\hline \multirow{2}{*}{ TSS (mg/l) } & $\mathrm{Q}_{1}$ & 93 & 18.90 & 26.30 & 34.10 & \multirow{2}{*}{27.00} & \multirow{2}{*}{30} \\
\hline & $\mathrm{Q}_{2}$ & 70 & 18.90 & 23.90 & 28.20 & & \\
\hline \multirow{2}{*}{$\mathrm{DO}(\mathrm{mg} / \mathrm{l})$} & $\mathrm{Q}_{1}$ & 0.00 & 3.80 & 3.73 & 3.68 & \multirow{2}{*}{0.95} & \multirow{2}{*}{3} \\
\hline & $\mathrm{Q}_{2}$ & 0.00 & 2.87 & 3.37 & 3.06 & & \\
\hline
\end{tabular}

From the summary of observations for the second stage of processing, the $\mathrm{pH}$ parameter of the three reactors MSL A, MSL B, and MSL C could meet the quality standard from 6.00-9.00. In comparing the $\mathrm{pH}$ parameter with the outflow water from the Integrated Sanitation outlet, the processing capability of the reactors in the second stage is better because the averages are close to the neutral $\mathrm{pH}$ of 7. For the TDS parameter, the three second-stage processing reactors could meet the quality standard of TDS below $1000 \mathrm{mg} / \mathrm{L}$, and compared with the Integrated Sanitation outlet, all reactors had a better average as they have lower average TDS values. For the TSS parameter, MSL A and MSL B could meet the quality standard of TSS below $30 \mathrm{mg} / \mathrm{L}$, but MSL C could not meet the quality standard. When compared to the Integrated Sanitation outlet, the conclusion is that the MSL A 
and MSL B reactors are better in processing suspended solids in domestic waste, but the MSL C reactor could not process solids better than the Integrated Sanitation facility. For the last parameter of DO, the three second-stage processing reactors could meet the Class III quality standard of above 3 $\mathrm{mg} / \mathrm{L}$; when compared to the Integrated Sanitation outlet with its value of $0.95 \mathrm{mg} / \mathrm{L}$, the conclusion is that the three reactors can result in a better DO value as they meet the Class III quality standard (Table 5).

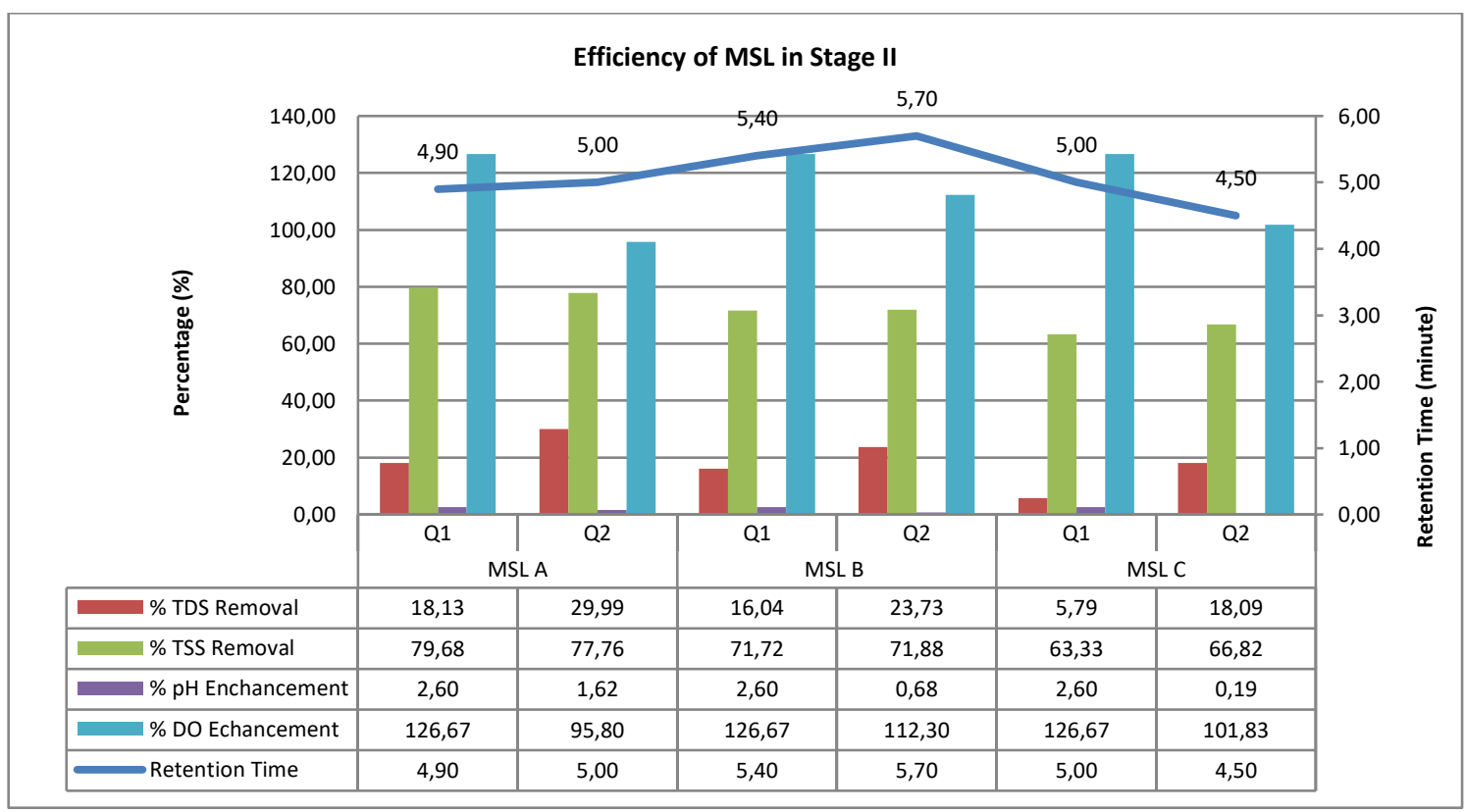

Figure 7. MSL System Efficiency for the Second Stage of Processing

The reactor with the best average efficiency for elimination of TDS concentration at the discharges of $\mathrm{Q}_{1}$ and $\mathrm{Q}_{2}$ was MSL A with a value of $24.06 \%$, followed by MSL B with $19.89 \%$ and MSL C with $11.94 \%$. The reactor with the best efficiency for the TSS parameter for both discharges was MSL A with $71.72 \%$, followed by MSL B with $71.80 \%$ and MSL C with $65.08 \%$. For the pH parameter, MSL $\mathrm{C}$ had the highest $\mathrm{pH}$ average enhancement efficiency of $2.11 \%$ from the initial $\mathrm{pH}$, followed by MSL B with $1.64 \%$ and MSL A with $1.40 \%$. For the DO parameter, MSL B had the greatest enhancement efficiency with $119.48 \%$ from the quality standard DO value, followed by MSL C with $114.25 \%$ and MSL A with $111.23 \%$ (Figure 7).

In this research, all the MSL systems linearly maintained a $\mathrm{pH}$ value of 7 . The nitrification capability to oxidize iron also differed for each reactor, and thus the release of hydroxyl groups into the bulk phase also differed [5,6]. For the $\mathrm{Q}_{1}$ discharge, there was a decrease in TSS elimination efficiency on average compared to elimination by layer of silica sand only (82\%) but with a high discharge $\left(\mathrm{Q}_{2}\right)$ there was an increase in TSS elimination efficiency, and this agrees with Latrach $[5,6]$ because TSS elimination is based on the mechanism of filtration and chemical adsorption that occurs on the soil mixture blocks. For the DO parameter, the overall DO value decreased because the oxygen present in the pores have been used in the process of nitrification and the pores have been occupied by wastewater, and thus an aeration process is needed to increase the performance of the MSL system. MSL A that utilized coconut shell charcoal had the best average efficiency for each parameter, followed by MSL B that utilized rice husk charcoal and MSL C with its corncob charcoal. According to the literature, coconut shell and rice husk charcoal contain high amounts of silica sand, which allows filtration of suspended solids; in addition, rice husk charcoal has a good porous quality with a low capability of water absorption, and the components of rice husk charcoal have a high amount of contained oxygen, which can increase the Dissolved Oxygen (DO) concentration. 
Mutia et al. [8] concluded that variations of organic material in soil mixture blocks, particularly the source of charcoal, gives a significant effect to the parameter of TSS and its elimination, as well as to the elimination of other pollutants. The results of filtration with combinations of the permeable layer with soil mixture blocks MSL A-s, MSL B ${ }_{-s}$, and MSL $\mathrm{C}_{-s}$ are shown in Figure 8.

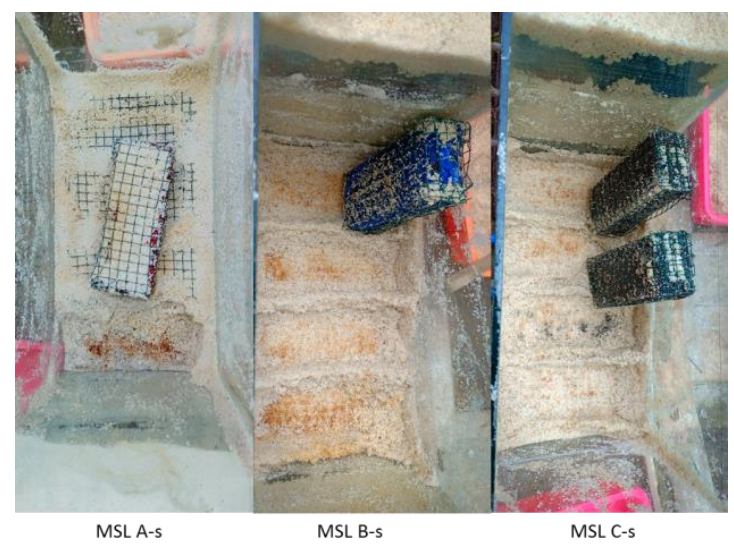

Figure 8. Color of Silica Sand with Nitrification Process Indications

Table 6. Selection of the Best Reactor in Stage II of Processing

\begin{tabular}{|c|c|c|c|c|c|c|c|}
\hline \multirow{2}{*}{ Parameter } & \multirow{2}{*}{ Factor } & \multicolumn{3}{|c|}{ Q1 } & \multicolumn{3}{|c|}{$\mathrm{Q} 2$} \\
\hline & & MSL A & MSL B & MSL C & MSL A & MSL B & MSL C \\
\hline \multirow[b]{2}{*}{ pH } & Meets Quality Standard & 1 & 1 & 1 & 1 & 1 & 1 \\
\hline & Best Ranking & 1 & 3 & 2 & 3 & 2 & 1 \\
\hline \multirow{2}{*}{ TDS } & Meets Quality Standard & 1 & 1 & 1 & 1 & 1 & 1 \\
\hline & Best Ranking & 3 & 2 & 1 & 3 & 2 & 1 \\
\hline \multirow{2}{*}{ TSS } & Meets Quality Standard & 1 & 1 & 0 & 1 & 1 & 1 \\
\hline & Best Ranking & 3 & 2 & 1 & 3 & 2 & 1 \\
\hline \multirow{2}{*}{ DO } & Meets Quality Standard & 1 & 1 & 1 & 1 & 1 & 1 \\
\hline & Best Ranking & 3 & 2 & 1 & 1 & 3 & 2 \\
\hline \multicolumn{2}{|l|}{ Total Score } & 14 & 13 & 8 & 14 & 13 & 9 \\
\hline \multicolumn{2}{|c|}{ Total Score of MSL A, Both Discharges } & 28 & & & & & \\
\hline \multicolumn{2}{|c|}{ Total Score of MSL B, Both Discharges } & 26 & & & & & \\
\hline \multicolumn{2}{|c|}{ Total Score of MSL C, Both Discharges } & 17 & & & & & \\
\hline
\end{tabular}

From the simple weighing method, the largest score was found to be 28 for MSL A (Table 6). The MSL reactor with the same soil mixture using coconut shell charcoal became the best free variable for the processing of wastewater in the second stage of processing. Coconut shell charcoal in comparison to the other types of charcoal was quite optimal in eliminating TDS and TSS at both discharges. The best ranking was taken from the results of quality measurements for each parameter; smaller concentrations of TDS and TSS means better processing. Higher concentrations of DO means that the oxygen content of the outflow wastewater increases, while for the $\mathrm{pH}$ parameter, as the outflow water reaches a neutral $\mathrm{pH}$ of 7 , its processing quality is enhanced.

\subsection{Third Stage of Processing}

Based on the results of measurement for 2.5 hours, 10 sets of observation data were obtained for each parameter at $\mathrm{Q}_{1}$ and $\mathrm{Q}_{2}$. Calculating the average values of the data gives a value that represents the resulting quality of outflow water from each reactor. 
Table 7. Summary of Water Quality Measurement for Stage III of Processing

\begin{tabular}{|c|c|c|c|c|c|c|c|}
\hline \multirow[b]{2}{*}{ Parameter } & \multirow[b]{2}{*}{ Discharge } & \multirow{2}{*}{$\begin{array}{c}\text { Aeration } \\
\text { Pond I }\end{array}$} & \multicolumn{3}{|c|}{ Reactor } & \multirow{2}{*}{$\begin{array}{c}\text { Integrated } \\
\text { Sanitation } \\
\text { Outlet }\end{array}$} & \multirow[b]{2}{*}{$\begin{array}{l}\text { Quality } \\
\text { Standard }\end{array}$} \\
\hline & & & $\begin{array}{l}\text { MSL A- } \\
\mathrm{m}\end{array}$ & MSL B-m & MSL C-m & & \\
\hline \multirow{2}{*}{$\mathrm{pH}$} & $\mathrm{Q}_{1}$ & 7.12 & 7.27 & 7.21 & 7.09 & \multirow{2}{*}{7.32} & \multirow{2}{*}{$6.00-9.00$} \\
\hline & $\mathrm{Q}_{2}$ & 7.14 & 6.93 & 7.07 & 7.06 & & \\
\hline \multirow{2}{*}{$\begin{array}{c}\text { TDS } \\
(\mathrm{mg} / \mathrm{l})\end{array}$} & $\mathrm{Q}_{1}$ & 705 & 494 & 471 & 524 & \multirow{2}{*}{584} & \multirow{2}{*}{1000} \\
\hline & $\mathrm{Q}_{2}$ & 715 & 510 & 495 & 564 & & \\
\hline \multirow{2}{*}{$\begin{array}{c}\mathrm{TSS} \\
(\mathrm{mg} / \mathrm{l}) \\
\end{array}$} & $\mathrm{Q}_{1}$ & 74 & 15.10 & 11.60 & 17.50 & \multirow{2}{*}{27.00} & \multirow{2}{*}{30} \\
\hline & $\mathrm{Q}_{2}$ & 93 & 20.60 & 18.10 & 27.50 & & \\
\hline \multirow{2}{*}{$\mathrm{DO}(\mathrm{mg} / \mathrm{l})$} & $\mathrm{Q}_{1}$ & 0.00 & 3.48 & 3.87 & 3.75 & \multirow{2}{*}{0.95} & \multirow{2}{*}{3} \\
\hline & $\mathrm{Q}_{2}$ & 0.00 & 2.81 & 3.25 & 3.01 & & \\
\hline
\end{tabular}

From the summary of observations for the third stage of processing, the $\mathrm{pH}$ parameter of the three reactors MSL A-m $-_{-m}$ MSL B-m $-_{-m}$ and MSL $\mathrm{C}_{-m}$ could meet the quality standard from 6.00-9.00. In comparing the $\mathrm{pH}$ parameter with the outflow water from the Integrated Sanitation outlet, the capability of all the MSL-m reactors is better because all three reactors approach the neutral $\mathrm{pH}$ of 7.00. For the TDS parameter, the three third-stage processing reactors could meet the quality standard of TDS below $1000 \mathrm{mg} / \mathrm{L}$, and compared with the Integrated Sanitation outlet, the outflow quality of the three MSL-m reactors showed lower values. The third-stage reactor that was the most efficient in processing TDS was MSL B $_{-m}$, with the average of the two discharges being $483 \mathrm{mg} / \mathrm{L}$. For the TSS parameter, the three MSL-m reactors could meet the quality standard of TSS below $30 \mathrm{mg} / \mathrm{L}$. In comparison with the Integrated Sanitation for the TSS parameter, the conclusion is that the three reactors are good and the MSL $B_{-m}$ reactor produces outflow wastewater with the lowest TSS value for the two discharges, being $14.85 \mathrm{mg} / \mathrm{L}$. For the last parameter of DO, the three third-stage processing reactors could meet the Class III quality standard of above $3 \mathrm{mg} / \mathrm{L}$; in comparison with the Integrated Sanitation with its value of $0.95 \mathrm{mg} / \mathrm{L}$, the conclusion is that the three reactors can result in a better DO value (Table 7).

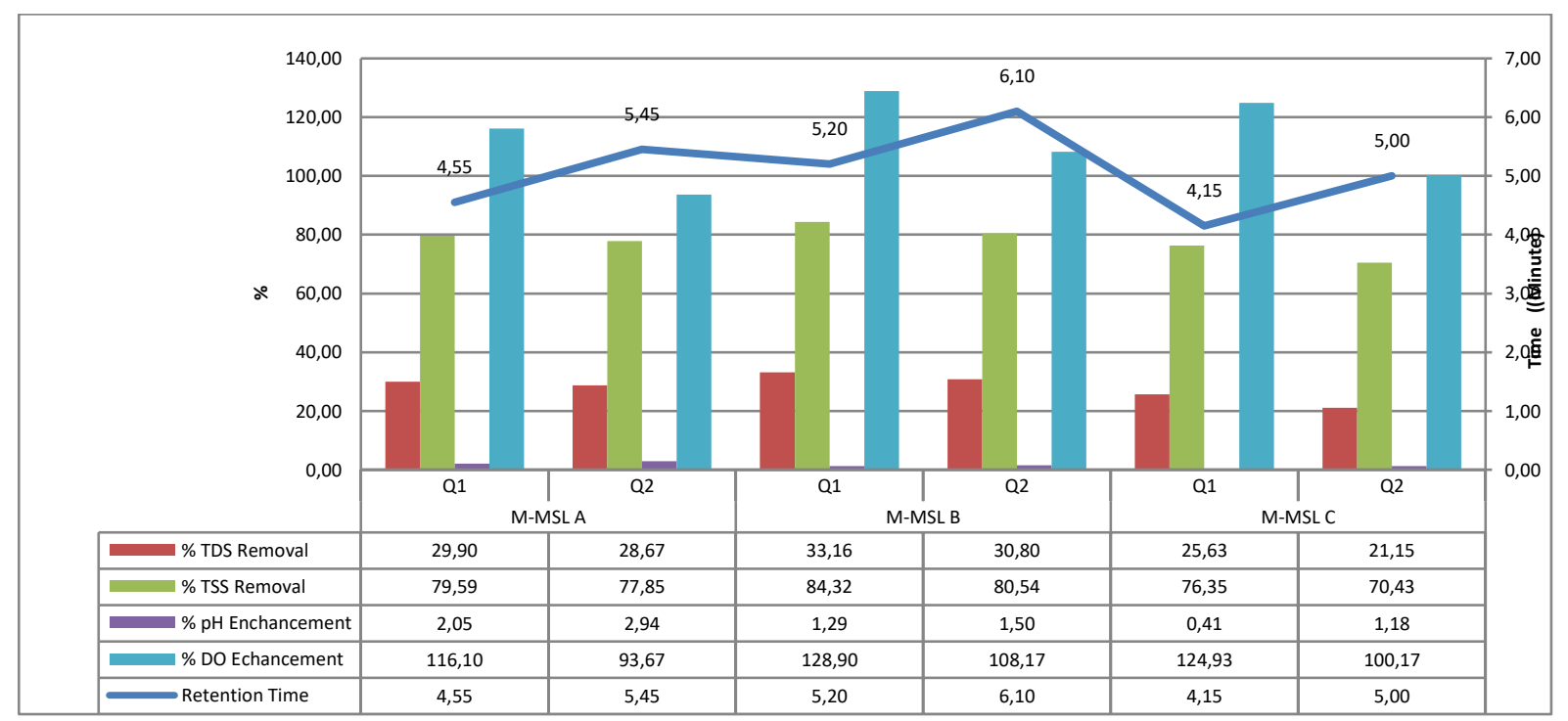

Figure 9. MSL System Efficiency for the Third Stage of Processing

The reactor with the best efficiency for the parameter TDS at both discharges was MSL B $_{-m}$ with a value of $31.98 \%$, followed by MSL $\mathrm{A}_{-\mathrm{m}}$ with $29.29 \%$ and MSL $\mathrm{C}_{-\mathrm{m}}$ with $23.29 \%$. The reactor with 
the best efficiency for the TSS parameter at both discharges was MSL B-m with $82.43 \%$, followed by MSL $C_{-m}$ with $78.72 \%$ and MSL $A_{-m}$ with $73.39 \%$. For the $\mathrm{pH}$ parameter, MSL $\mathrm{A}_{-\mathrm{m}}$ had the highest $\mathrm{pH}$ enhancement efficiency with $2.11 \%$ from the initial $\mathrm{pH}$, followed by MSL $\mathrm{B}_{-\mathrm{m}}$ with $1.59 \%$ and MSL $\mathrm{C}_{-\mathrm{m}}$ with $1.40 \%$. For the DO parameter, MSL $\mathrm{B}_{-\mathrm{m}}$ had the greatest enhancement efficiency with $118.53 \%$ from the DO quality standard, followed by MSL $\mathrm{C}_{-\mathrm{m}}$ with $112.55 \%$ and MSL $\mathrm{A}_{-\mathrm{m}}$ with $104.88 \%$ (Figure 9).

Table 8. Selection of the Best Reactor in Stage III of Processing

\begin{tabular}{|c|c|c|c|c|c|c|c|}
\hline \multirow{2}{*}{ Parameter } & \multirow{2}{*}{ Factor } & \multicolumn{3}{|c|}{ Q1 } & \multicolumn{3}{|c|}{ Q2 } \\
\hline & & M-MSL A & M-MSL B & M-MSL C & M-MSL A & M-MSL B & M-MSL C \\
\hline \multirow{2}{*}{$\mathrm{pH}$} & Meets Quality Standard & 1 & 1 & 1 & 1 & 1 & 1 \\
\hline & Best Ranking & 1 & 2 & 3 & 1 & 3 & 2 \\
\hline \multirow{2}{*}{ TDS } & Meets Quality Standard & 1 & 1 & 1 & 1 & 1 & 1 \\
\hline & Best Ranking & 2 & 3 & 1 & 2 & 3 & 1 \\
\hline \multirow{2}{*}{ TSS } & Meets Quality Standard & 1 & 1 & 1 & 1 & 1 & 1 \\
\hline & Best Ranking & 2 & 3 & 1 & 2 & 3 & 1 \\
\hline \multirow{2}{*}{ DO } & Meets Quality Standard & 1 & 1 & 1 & 1 & 1 & 1 \\
\hline & Best Ranking & 1 & 3 & 2 & 1 & 3 & 2 \\
\hline \multicolumn{2}{|l|}{ Total Score } & 10 & 15 & 11 & 10 & 16 & 10 \\
\hline \multicolumn{2}{|c|}{ Total Score of M-MSL A, Both Discharges } & 20 & & & & & \\
\hline \multicolumn{2}{|c|}{ Total Score of M-MSL B, Both Discharges } & 31 & & & & & \\
\hline \multicolumn{2}{|c|}{ Total Score of M-MSL C, Both Discharges } & 21 & & & & & \\
\hline
\end{tabular}

In the third stage, it became evident that there was a significant difference on MSL B for which

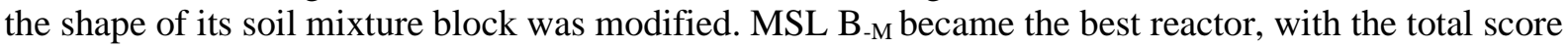
of $\mathrm{Q}_{1}$ and $\mathrm{Q}_{2}$ discharges being 31, followed by MSL $\mathrm{C}_{-\mathrm{M}}$ and MSL $\mathrm{A}_{-\mathrm{M}}$ (Table 8). It can be noticed that the results of the MSL $\mathrm{B}_{-\mathrm{M}}$ outflow for each parameter was dominantly constant and unchanging. According to Latrach et al. [5, 6], the addition of soil mixture in MSL-M to form the letter U shape can slow down contact of wastewater with the soil, which can maximize each process that occurs in MSL (filtration, aerobic decomposition, adsorption, nitrification, and denitrification). The following is a comparison of the processing efficiency of the MSL B reactor before modification (MSL B-s) and after modification (MSL B $_{-M}$ ) of the soil block shape:

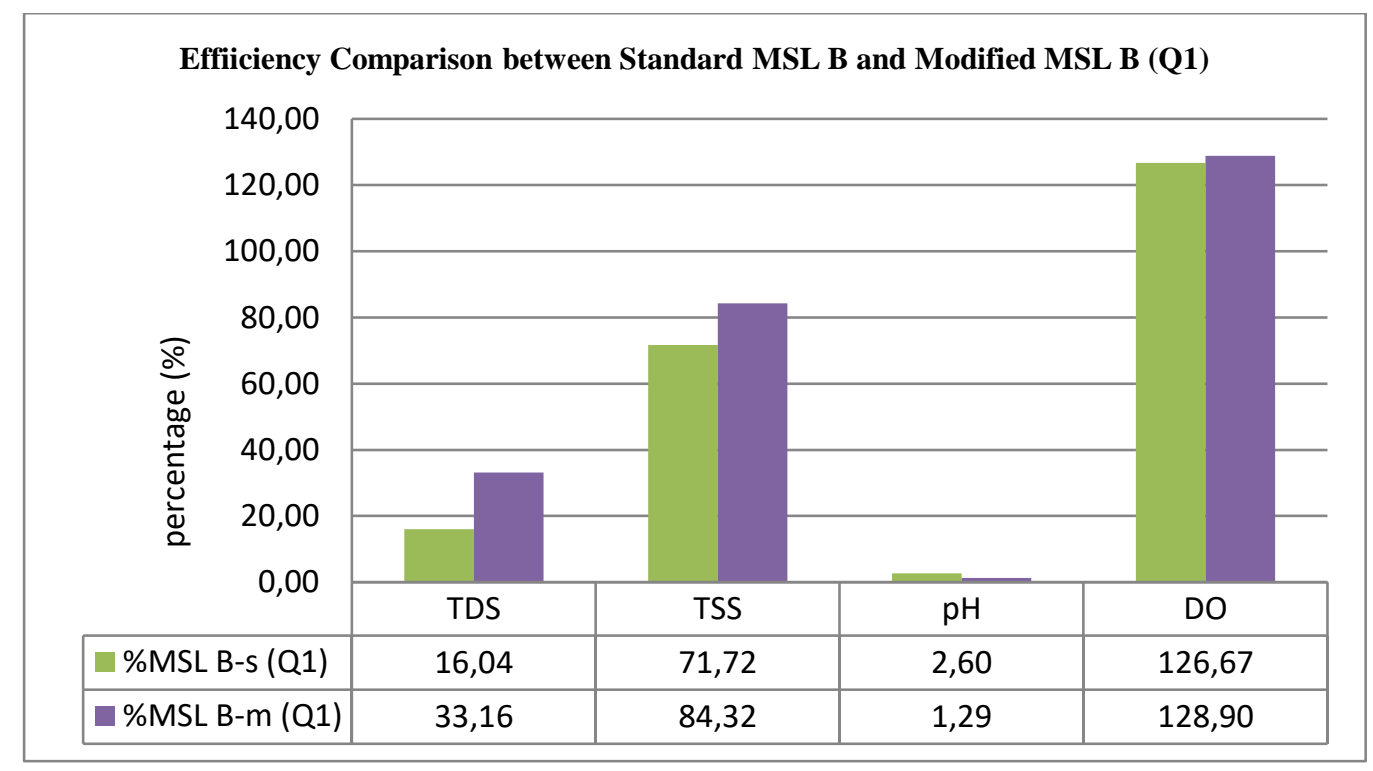

Figure 10. Efficiency Comparison of MSL B-s and MSL B-m Reactors 
By taking the example of the efficiency MSL B-s and MSL B-m at $\mathrm{Q}_{1}$ it can be seen that the MSL that had been modified has a tendency to increase in efficiency. At a discharge of $0.0063 \mathrm{~L} / \mathrm{second}$, the increase in efficiency from stage II to stage III for the TDS parameter was $17.12 \%$. The increase of the TSS parameter was $12.6 \%$. The $\mathrm{pH}$ parameter had a decrease in efficiency of $1.31 \%$ and the increase in efficiency for the parameter DO was 1.93\% (Figure 10). By looking at the scores of the three stages of processing, it can be concluded that for all stages, the MSL B $_{-M}$ reactor with a score of 31 can be regarded as the best reactor (Table 8).

\section{CONCLUSION}

The multi-soil-layering (MSL) system was tested with three reactor columns and three stages of processing in this research. In the first stage of processing, zeolite and pumice could not meet the quality standard for the TSS parameter, while the effluent from silica sand was able to meet the quality standard and was selected as the best rock layer for the subsequent stage of processing. In the second stage of processing, MSL A-s, MSL B-s, and MSL C-s at both discharges could meet the quality standards for each parameter. At $\mathrm{Q}_{1}$, MSL A-s had the best elimination capability, with the efficiencies of TDS, TSS, pH, and DO respectively being $18.13 \%, 79.68 \%, 2.60 \%$, and $126.67 \%$, while at $\mathrm{Q}_{2}$ they were $29.99 \%, 77.76 \%,-1.62 \%$, and $95.80 \%$. In the third stage of processing that utilized a modification of soil mixture blocks, MSL A-m, MSL B-m, and MSL C-m increased in their efficiencies in comparison to the standard unmodified MSL reactor. At the third stage, each parameter at both utilized discharges indicated that MSL B-m was the most optimal reactor compared to all reactors that had their water quality measure. At $\mathrm{Q}_{1}$, the efficiencies of MSL B-m for the TDS, TSS, $\mathrm{pH}$, and DO parameters respectively were $33.16 \%, 84.32 \%, 1.29 \%$, and $126.67 \%$ while at $\mathrm{Q}_{2}$ they were $30.80 \%, 80.54 \%,-1.50 \%$, and $112.30 \%$. Considering the change in water quality of the outflow for each processing, the hypothesis is that MSL reactors do not have a uniform effect on the $\mathrm{pH}$ parameter. The resulting percentages of efficiency from reactors with longer retention times has a tendency to be greater compared to reactors with shorter retention times; this is related to the length of interaction and the contact time between wastewater and the processing materials, as rocks and soil mixtures.

The reactor outflow results, in comparison with the Integrated Sanitation outlet, show that they are better in processing domestic wastewater with a relatively quick processing time, but there needs to be periodic rinsing of the silica sand granules and the soil mixture blocks so that the pores of the materials are not clogged by suspended solids. There needs to be further research on modifications to the MSL system through the measurement of other pollutant parameters as well as research using other materials in order to provide further comparisons and literature.

\section{References}

[1] An, C.J., McBean, E., Huang, G.H., Yao, Y., Zhang, P., Chen, X.J., Li, Y.P. 2016. Multi-SoilLayering Systems For Wastewater Treatment In Small And Remote Communities. J. Environm. Inf. 27, 131-144. http://dx.doi.org/10.3808/jei.201500328.

[2] An, C.J., McBean, E., Huang, G.H., Yao, Y., Zhang, P., Chen, X.J., Li, Y.P. 2016. Multi-SoilLayering Systems For Wastewater Treatment In Small And Remote Communities. J. Environm. Inf. 27, 131-144. http://dx.doi.org/10.3808/jei.201500328.

[3] Guan, Y., Zhang, Y., Zhong, C.N., Huang, X.F., Fu, J., Zhao, D. 2015. Effect Of Operating Factors On The Contaminants Removal Of A Soil Filter: Multi-Soil-Layering System. Environ. Earth Sci. 74 (3), 2679-2686. http://dx.doi.org/10.1007/s12665-015-4288-8.

[4] Lestari, H., Haribowo, R., \& Yuliani, E. (2019). Determination of Pollution Load Capacity Using QUAL2Kw Program on The Musi River Palembang. Civil and Environmental Science Journal, 2(2), pp.105-116. doi:https://doi.org/10.21776/ub.civense.2019.00202.4

[5] Latrach, L., Ouazzani, N., et al. 2018. Optimization Of Hydraulic Efficiency And Wastewater Treatment Performances Using A New Design Of Vertical Flow Multi-Soil-Layering (MSL) Technology Ecological Engineering. 140-152. https://doi.org/10.1016/j.ecoleng.2018.04.003 
[6] Latrach, L., Masunaga, T., Ouazzani, N., Hejjaj, A., Mahi, M., Mandi, L., 2015. Removal Of Bacterial Indicators And Pathogens From Domestic Wastewater By The Multi-Soil Layering (MSL) System. Soil Sci. Plant Nutr. 61, 337-346. http://dx.doi.org/10.1080/ 00380768.2014.974480.

[7] Megah, S., Rosita, W., Haribowo., R. 2018. Efisiensi Pengolahan Limbah Domestik Menggunakan Metode Multi Soil Layering (MSL). Jurnal Teknik Pengairan Universitas Brawijaya, 1-13.

[8] Mutia, R., Elystia, S., Yenie, E. 2015. Metode Multi Soil Layering Dalam Penyisihan Parameter TSS Limbah Cair Kelapa Sawit Dengan Variasi Hydraulic Loading Rate (HLR) Dan Material Organik Pada Lapisan Anaerob. Jom FTEKNIK Volume 2 No. 1 Februari 2015. 16.

[9] Riyanto H, Minami Y, Masahiko S, Tsuyoshi I, Koichi Y, Takaya H, Ariyo K 2017 Behavior of toxicity in river basins dominated by residential areas Contemporary Engineering Sciences 10 (7), 305-315.

[10] R Haribowo, V Dermawan, SN Yudha., 2018. Application of Artificial Neural Network For Defining The Water Quality in The River. Civil and Environmental Science Journal 1 (01), 12-18, 2018.

[11] Yamashita H, Haribowo R, Sekine M, Oda N, Kanno A, Shimono Y 2012 Toxicity test using medaka (Oryzias latipes) early fry and concentrated sample water as an index of aquatic habitat condition Environmental Science and Pollution Research 19 (7), 2581-2594.

[12] Deshpande, V. V., \& Thorvat, A. R. (2018). Experimental Investigation of Treatment of Domestic Wastewater Using Multi Soil Layering (MSL) System. Aquademia: Water, Environment and Technology, 2(2), 05. https://doi.org/10.20897/awet/3963.

[13] Yidong Guan, Chen Xin, Zhang Shuai, Luo Ancheng. 2012. Performance of multi-soil-layering system (MSL) treating leachate from rural unsanitary landfills. Science of The Total Environment 420:183-90. DOI: 10.1016/j.scitotenv.2011.12.057 